(This is a combined version of two articles: “Do You Want To Know A Secret?': Popular Music in Perth in the Early 1960s' online in Illumina: An Academic Journal for Performance, Visual Arts, Communication \& Interactive Multimedia, 2007, available at: http://illumina.scca.ecu.edu.au/data/tmp/stratton\%20j\%20\%20illumina\%20p roof\%20final.pdf and 'Brian Poole and the Tremeloes or the Yardbirds: Comparing Popular Music in Perth and Adelaide in the Early 1960s' in Perfect Beat: The Pacific Journal for Research into Contemporary Music and Popular Culture, vol 9, no 1, 2008, pp. 60-77).

\title{
Brian Poole and the Tremeloes or the Yardbirds: Comparing Popular Music in Perth and Adelaide in the Early 1960s
}

In this article I want to think about the differences in the popular music preferred in Perth and Adelaide in the early 1960s-that is, the years before and after the Beatles' tour of Australia and New Zealand, in June 1964. The Beatles played in Sydney, Melbourne, Brisbane and Adelaide but not in Perth. In spite of this, the Beatles' songs were just as popular in Perth as in the other major cities. Through late 1963 and 1964 'I Want to Hold Your Hand,' 'I Saw Her Standing There,' 'Roll Over Beethoven' and the 'All My Loving' EP all reached the number one position in the Perth chart as they did nationally. ${ }^{1}$ In this article, though, I am not so much interested in the Beatles per se but rather in their indexical signalling of a transformation in popular music tastes.

As Lawrence Zion writes in an important and surprisingly neglected article on 'The impact of the Beatles on pop music in Australia: 1963-1966:' 'For young Australians in the early 1960s America was the icon of pop music and fashion.' ${ }^{2}$ One of the reasons Zion gives for this is the series of Big Shows put on by American entrepreneur Lee Gordon through the second half of the 1950s. Starting with jazz artists including Ella Fitzgerald, Artie Shaw and Louis Armstrong, Gordon progressed by way of Johnnie Ray to rock'n'roll including both white acts such as Bill Haley and the Comets, Gene Vincent and Connie Francis and African-Americans such as Big Joe Turner, La Vern Baker and Little Richard. ${ }^{3}$ Gordon's Big Shows played the east coast cities but never reached either Adelaide or Perth. Gordon brought Little Richard to 
Australia in 1957. It is in this context that he reached the top thirty nationally five times during 1956 and 1957 but did not make the Perth singles chart until 1958 when 'Good Golly Miss Molly’ made it to number thirteen and the Adelaide chart until 1970 when 'Freedom Blues' got to number sixteen.

One reason for the difference in impact in Adelaide and Perth between the Big Shows and the Beatles was the advent of television, which began in Adelaide as in Perth in 1959, three years after the first broadcasts in Sydney and Melbourne. Television drew Adelaide and Perth more closely into the cultural developments taking place in the eastern states. One of these related to the Beatles' tour. The visit by the Beatles marks a shift in influence from the American rock'n'rollers to the English groups who had absorbed the American music and integrated it with aspects of the English musical tradition. However, this shift had been taking place since early 1963 when the new English group sound had started to show up on the Australian charts with Gerry and the Pacemakers and, later in the year, Billy J. Kramer with the Dakotas, Brian Poole and the Tremeloes and the Searchers.

Moreover, while Zion is right to identify the importance of American rock'n'rollers on Australian popular music during the 1950s, we should remember that there was an underlying English influence. Tommy Steele, for example, reached the top one hundred nationally five times between 1958 and 1960 getting to number three in 1960 with his remake of Harry Champion's 1905 music hall song, 'What A Mouth.' Similarly, Adam Faith reached number twenty-two in March 1960 with 'What Do You Want?' and the lower reaches of the top one hundred another four times between 1960 and 1963. However, the best example of the importance of English music in Australia before the beat groups of 1963 is Cliff Richard and the Shadows both together and the Shadows in their own right.

While originally marketed, like Tommy Steele, as Britain's answer to Elvis Presley, with his flashing white-toothed smile, relaxed and respectful manner and modulated English accent Richard rapidly became the quintessential English entertainer. With his clear and warm tenor voice, his well-enunciated lyrics and songs that had a bounce in their light beat that made them more crooner than music hall, Richard's 
releases appealed to the mainstream youth and young-adult audience. In Britain, all his releases up to 1968 made the top twenty with the exception of three which got into the twenties. Nine of them, including 'Livin' Doll,' 'Please Don’t Tease' and 'The Young Ones’ reached number one.

At the same time, those middle-class, homely qualities that endeared Richard so much to British audiences made him appear banal to an American audience whose most popular solo artists of the 1950s and early 1960s were Frank Sinatra and then Elvis Presley, both of whom sang with a sexual charge in their voice and gave off a feeling of macho menace. In the United States, Richard’s highest placing up till 1976 was number twenty-five with the ballad 'It's All In The Game' while 'Livin' Doll' climbed to number thirty and his other releases, at best, got into the lower half of the top one hundred.

In Australia, the story is much more similar to Britain. While Richard has never had a number one nationally, twenty of his releases made the top ten up to 1968. When we look at the chart placings for Adelaide and Perth the story becomes more complicated. Over the sweep of his releases between 1959 and 1968 we find that Richard did consistently better in Perth, and often better in Adelaide, than he did nationally. Thus, for example, 'Livin’ Doll' reached number nine nationally in 1959 but got to number three in Adelaide and number six in Perth, 'Please Don't Tease' (1965) got to number two nationally but number one in Perth, 'The Young Ones' (1962) got to number six nationally, number seven in Adelaide but number one in Perth, 'Bachelor Boy' (1963) got to number nine nationally, only number twenty-six in Adelaide but got to number five in Perth, and so on. The Shadows, practically unknown in the United States, had thirteen top ten hits in Britain between 1959 and 1963 and eleven top ten hits in Australia in the same period. In Adelaide and Perth, generally speaking, the Shadows' releases were comparably successful to their national success. With the greater success of Richard in Perth than in Adelaide and nationally we can begin to see a pattern that becomes more obvious over the next decade. It seems that the record buyers of Perth were more attuned to English music, and to English music more at the entertainment end of the spectrum, than audiences elsewhere in Australia. 
In Zion's article on the Beatles in Australia he is particularly concerned with demonstrating the relationship between the large migration of Britons during the later 1950s and early 1960s and the rapid development of beat bands in Australia. Zion's focus is on Adelaide where, as I have already remarked, the Beatles were not originally planned to play. However, a disc jockey called Bob Francis organised a petition which gained eighty-thousand signatures. This pressure, and it almost goes without saying, as Glenn A. Baker documents in his book on the tour, the lure of more money for both the organisers and the artists, led to Adelaide being included in the itinerary. ${ }^{4}$

When the Beatles arrived in Adelaide somewhere in the region of 300,000 people went to the airport and lined the streets to welcome them. Zion's point is that this extraordinary turn-out, and the surprisingly high number of beat bands, who originated from Adelaide, was directly related to the high percentage of British migrants in Adelaide and their concentration in the new suburb of Elizabeth, founded in 1955. Zion writes that:

'Between 1954 and 1966 almost a quarter of a million British-born immigrants arrived in Australia, which, while only marginally increasing the British-born proportion of the population, still maintained a strong British contingent within Australian society. Of particular significance is the uneven spread of these new immigrants. Over a quarter of them settled in South Australia, which almost doubled their proportion of the population in that state to over 11 per cent, which far exceeded the national figure of less than 8 per cent. And of special importance was their intense concentration in Adelaide's new satellite city, Elizabeth, where, by 1966, almost 45 per cent of the population had been born in Britain. ${ }^{5}$

Zion writes about British migrants, however, we can get a more accurate understanding of the origins of these migrants from R. T. Appleyard's survey of a sample of 2,411 migrants which he conducted in 1959. This represented $20 \%$ of the migrants who travelled to Australia by assisted passage in that year. Of these, 
5.8\% came from Wales, $13.7 \%$ were from Scotland while the remaining $80.5 \%$ were from England. ${ }^{6}$

Zion does not mention Perth in his article. I.H. Burnley, in his discussion of 'British Immigration and Settlement in Australian Cities, 1947-1971' writes that, 'by 1971 the British constituted over 17 percent of the total population of metropolitan Perth, and 15 percent of metropolitan Adelaide's compared to 8 and 9 percent of Melbourne's and Sydney's populations. ${ }^{7}$ In 1961 Adelaide had a population of around 588,000. Perth's population was rather smaller at just over 420,000. By 1971, Perth's population had increased to nearly 642,000 and Adelaide's to 843,000. By this time, Perth had the highest proportion of British migrants of any major Australian city, closely followed by Adelaide. Here then, in addition to these cities missing out on the Big Shows, is another reason why English popular music, rather than American, was more preferred in Adelaide and Perth.

Perth, however, did not produce the same efflorescence of beat groups as Adelaide. Indeed, the musical profile of Perth was quite different to that of Adelaide. Where Adelaide produced not only the heavily Beatles-influenced Twilights but also a surprising number of groups, such as the Others, Masters Apprentices, and Zoot, many of them, as we shall see, influenced by the English rhythm and blues groups, Perth's most significant musical exports to the rest of Australia at this time were the Valentines, who finished their career as a teeny-bop bubblegum act in Melbourne, and the mainstream pop singer Johnny Young. Could this difference be a result of the Beatles not coming to Perth? This seems unlikely, especially as, as I have already noted, Beatles' releases were as popular in Perth as elsewhere in Australia. Could the difference be attributable to the greater diffusion of British migrants in Perth than Adelaide? We need to start by looking at the differences in the situation of British migrants settling in Adelaide and in Perth.

\section{British Migrants in Adelaide and Perth}

I have already noted that by 1971 seventeen percent of the Perth population, as compared to fifteen percent of Adelaide's population, was made up of British migrants. In 1986 James Jupp conducted a comparative study of two federal electorates with very high concentrations of British migrants, Bonython in South Australia-the electorate 
which includes Elizabeth—and Canning in Western Australia in the southern suburbs of Perth. Jupp compared the dates of arrival for the British migrants in each electorate:

'The settlement of British migrants in Bonython occurred in a direct response to state public policy, which was reflected in their concentrated dates of arrival. Just half had arrived between 1960 and 1969 compared with slightly over one third in Canning. Almost no one in Bonython had arrived before 1950 or after 1980. Those in Canning had a more varied experience: two thirds had arrived between 1960 and 1979, about 8 percent before 1950 and 7 percent since $1980 .^{\text {, }}$

In Canning, then, while there was a large influx of British during the 1960s it was not as great as the migration to Bonython and, also, in Canning this British migration was modulated by earlier migration in the 1950s and, which does not concern us here, after 1980. It is reasonable to generalise these figures across Perth and Adelaide. Arguably, the nineteen per cent of British migrants that arrived in the 1950s accounts for the Perth preference for English solo singers over the beat groups. It is here that we find the reason for Perth's preference for Cliff Richard compared to Adelaide, which took a relatively smaller number of British migrants in the 1950s. More, the proportionally much smaller numbers of British migrants in the other major cities accounts for the comparative lack of popularity of Richard nationally. However, in Adelaide, the more than fifty percent of British — though, as we have seen, mainly English—migrants who arrived between 1960 and 1969 were an important factor in that city’s preference for beat groups.

In Perth the large numbers of British migrants that settled in the 1960s came in response to the rapid expansion of job opportunities caused by the increase in wealth which, in turn, was caused by the resources boom in the Pilbara after the discovery of the huge deposit of iron ore at Tom Price and the lifting of the iron ore export embargo. These jobs were not in large scale urban industrial manufacturing. Perth's wealth remained a consequence of primary industry. That these new migrants settled in particular areas was a consequence of chain migration rather than government policy. The effect of this was that even though British migrants did concentrate in suburbs such as Armadale, Kwinana and Rockingham they were more generally dispersed across Perth 
than those migrants who were encouraged to go to Adelaide and found themselves directed towards Elizabeth.

The situation in Adelaide was very different to Perth. The first idea for Elizabeth was that it should be a new town on the British post-Second World War model. Building started in 1954. Elizabeth was to be reasonably self-reliant fulfilling Premier Sir Thomas Playford's 'strategy of cheap housing, industrialisation and regional security. ${ }^{9}$ It was to have a mixed middle-class and working-class population. When General Motors Holden agreed to build their new factory in Elizabeth in the late 1950s, things began to change:

'The immediate impact of the GMH deal was an overhaul of the plan to accommodate both the factory and the expected increase in the labouring population. The area devoted to industry, along with the corresponding residential and open space areas, were doubled in size., ${ }^{10}$

Mark Peel remarks that: 'By 1960 it was becoming clear that Elizabeth’s fortunes would depend on its industries.' ${ }^{11}$ Elizabeth would become primarily, if not completely, working-class. This was the environment into which British migrants were recruited during the 1960s. As Peel writes: 'Effectively, migrants were the best available means of populating Elizabeth quickly.' ${ }^{12}$

In 1964 R.T. Appleyard published his survey of British migrants who had arrived in Australia during the 1950s and early 1960s. He found that 'by 1959 there were not enough skilled applicants for assisted passages to fill the 'targets' set by the Australian government and a larger than usual number of nominations had to be offered to semiskilled and unskilled workers.' ${ }^{13}$ From his survey Appleyard discovered that, 'better opportunities for self and the children were the main reason of 74 per cent of all husbands ${ }^{, 14}$ who migrated. A large number of these British working-class migrants, as typified in Appleyard's sample, would move to Elizabeth over the coming years. There they would seek that better life that inspired them to migrate. Elizabeth, however, as Peel writes, 'became a workers' city, a place organised around the earning power of adult men and the paid and unpaid work of the adult women who translated wages into security, comfort and improvement. ${ }^{15}$ The majority of these workers were employed by the Weapons Research Establishment and GMH. The better future of which these families 
had dreamed was lost in migration. What I will argue is that this disappointment can be directly related to the kind of music which became popular in Adelaide.

In Adelaide, beat groups such as Brian Poole and the Tremeloes and Billy J. Kramer with the Dakotas, at the sweeter, poppier end of the beat spectrum, did better than nationally but not as well as they did in Perth. There is a strong correlation here between the cities with the highest proportions of British migrants and the success of these English groups. At the same time we need ask why this sound was less popular in Adelaide and if there was another sound that was more popular in Adelaide than Perth or nationally. And if there was, then we need to account for the distinctive preferences of the two cities.

\section{Popular Music in Perth}

While the Beatles never got to Perth another 'Merseybeat' show did. Kenn Brodziak had booked the Beatles to tour in mid-1963, a year before they arrived in Australia. 'From Me To You' had reached number one in Britain in May. 'Please Please Me' had been released in January and go to number two. 'Love Me Do,' the Beatles first single had reached number seventeen in 1962. In Australia, 'Please Please Me' got to number fifty two nationally, number thirteen in Adelaide but did not chart in Perth — that is, it did not make what was then a top forty. 'From Me To You' made number nine nationally, number five in Adelaide and number ten in Perth. What these figures suggest is that Adelaide, as Zion's argument would suggest, picked up on the Beatles' music first of the major cities while Perth, in spite of its higher percentage of British migrants, took longer than the other capitals to appreciate what the Beatles were offering. At the same time we should remember that Cliff Richard was more popular in Perth than in any other capital city in Australia. In other words, it would seem that it was the musical innovation that the Beatles offered that was resisted in Perth and that this was in part a consequence of the migrants who had arrived in the 1950s with a very different musical taste.

When the phenomenon of the beat sound, located most significantly in Liverpool, started to take off in Australia in mid-1963, Harry M. Miller set about booking his own 'Liverpool Sound' show to tour the capital cities, including Perth. 'The World's Top Record Sensations on the Wild “Liverpool Sound” Show,' as they were advertised,

played three sets in Perth at a converted cinema, the Capitol Theatre, on Saturday $4^{\text {th }}$ 
April 1964, two months before the Beatles came to Australia. Headlining the show were Gerry and the Pacemakers. Dusty Springfield opened after her backing group, the Echoes, had played a warm-up set. Also on the bill were Gene Pitney and Brian Poole and the Tremeloes. Dusty Springfield was a blue-eyed soul singer who came from London and had previously been in a vocal trio called the Springfields. Brian Poole and the Tremeloes came from Dagenham in Essex. Gene Pitney was American. Miller, it seems, called the show the 'Liverpool Sound' to capitalise on the presence of Gerry and the Pacemakers.

Gerry and the Pacemakers, who like the Beatles were managed by Brian Epstein, were the first of the beat bands to the top the singles chart in Britain. 'How Do You Do It?' got to number one in March 1963. Their two subsequent releases, 'I Like It' and 'You'll Never Walk Alone' also reached number one later in 1963 making this the first time any artist had made number one in Britain with their first three singles. At the beginning of 1964, then, Gerry and the Pacemakers were at least as popular as the Beatles. However, by the time they arrived in Australia their popularity in both countries had been eclipsed by that of the Beatles. Nationally, Gerry and the Pacemakers' first three singles reached numbers three, six and one respectively during 1963 . When the tour flew into Sydney they were met at the airport by a mere forty fans. ${ }^{16}$ In Adelaide they were greeted by 10,000 fans. ${ }^{17}$ In Perth, The West Australian reported that: 'A teenage crowd of almost 4,500 at Perth Airport last night welcomed a team of English entertainers. ${ }^{, 18}$

On the evidence of the singles charts, Gerry and the Pacemakers' popularity was roughly the same across all the cities though it should be pointed out that it was only in Perth that the group's first single got to number one. While it took a while for Perth to appreciate the Beatles, as with the British there was a more immediate connection with the music of Gerry and the Pacemakers. What difference between the two groups might account for this? Both groups had honed their skills in the Hamburg clubs where the distinctive combination of off-beat and melody in a four piece group including lead and rhythm guitars, bass and drums had been perfected. However, the crucial difference between the two groups was the African-American-originated rhythm and blues edge which John Lennon, in particular, brought to the Beatles' sound. In contrast, Gerry 
Marsden, who was sometimes billed as 'Mr Personality of Merseyside,' was much more of an entertainer in the English music hall and Variety tradition. In his book on the English groups in Hamburg, Alan Clayson describes Gerry Marsden as:

'a show-biz natural of boy-next-door ilk. His grinning vibrancy, strong voice and compelling patter gilded fretboard skills that were to be finetuned through paying acute attention to Tony Sheridan [an English rocker who had established himself in Hamburg] as had the Beatles. ${ }^{19}$

Ritchie Unterberger at AllMusic Guide writes that the group, 'defined [Merseybeat] at its most innocuous, performing bouncy, catchy, and utterly lightweight tunes driven by rhythm guitar and Marsden's chipper vocals. ${ }^{20}$ Gerry and the Pacemakers' forte was bouncy, melodic pop and sentimental ballads. 'You'll Never Walk Alone' was a Rodgers and Hammerstein composition from the musical Carousel which Marsden remembered from his youth. The later, nostalgic and schmaltzy, 'Ferry Across The Mersey,' which reached number two nationally in Australia in 1965, and number one in Perth, was written by Marsden. Even the rhythm and blues songs the group covered, such as Larry Williams' 'Slow Down,' acquired the music hall bounce. In this regard it is worth comparing Gerry and the Pacemakers' version of the song with the Beatles' version released on their Long Tall Sally EP in 1964 with the vocal by John Lennon. The Beatles' version has a harder beat and a more emotional vocal. What Gerry and the Pacemakers had in common with Cliff Richard, then, was that they were, basically, Variety entertainers. We can already, then, begin to see a pattern developing in the musical preferences of Perth's population in the early 1960s.

I need to say something briefly here about Variety. In Britain respectable musical taste was reflected in the kinds of music available in the programs on television such as Sunday Night at the London Palladium, which ran from 1955-1967, and The Black and White Minstrel Show, which ran from 1958 to 1978. These typified Variety. On radio, Variety included programs such as The Billy Cotton Band Show which ran on the Light Programme between 1949 and 1968. Variety had a lineage in music hall. With the advent of mass media what had started out as a working-class entertainment became a mass entertainment and took on the values of the middle class. Variety shows included a 
selection of artists such as jugglers, dancing troupes, acrobats and comics as well as singers. The beat music that gained acceptance in Variety was highly melodic, often with a sing-along-style chorus, and a bouncy, rather than driving, beat. It was music to be enjoyed rather than music which provoked emotion. It was white, English music with a beat, the music of the music hall and the working-class pub sing-along but cleaned-up and made subject to middle-class respectability, rather than music influenced by the African-American tradition.

This preference in Perth for the lighter, poppier end of the beat sound spectrum is more clearly demonstrated in the reception of the other group of the 'Liverpool Sound' tour, Brian Poole and the Tremeloes. Roslyn Owen, who reviewed the show for The West Australian, commented that 'Jerry [sic] Marsden, backed by his Pacemakers, had tremendous attack, a wide grin and a loud presentation.’ However, Owen preferred Brian Poole and the Tremeloes:

'Why Gerry and the pacemakers [sic] topped the bill is a mystery.

The group was outshone by Brian Poole and the Tremeloes and the professional polish and charm of Miss Dusty Springfield. ${ }^{21}$

Owen had her finger on the pulse of Perth record buyers' tastes. Between 1963 and 1965 when Brian Poole left to pursue a solo career, every hit that the group had in Australia was more successful in Perth than nationally, with Adelaide coming between the two. Thus, 'Do You Love Me' (1963) reached number nineteen nationally, number nine in Adelaide and number two in Perth. 'I Can Dance' (1964) reached number twenty-four nationally, number twenty-four in Adelaide and number twelve in Perth. 'Candy Man' (1964), reached number nineteen nationally, number eighteen in Adelaide and number six in Perth. The group's cover of the Crickets' 'Someone Someone' reached number seventeen nationally, number six in Adelaide and number two in Perth.

Brian Poole and the Tremeloes were formed in 1959, around the same time as Gerry and the Pacemakers and other beat bands formed. However, their career path was quite different to that of the Merseybeat groups. Rather than playing rhythm and blues in the clubs of Hamburg's red light district, Brian Poole and the Tremeloes put together a set of Buddy Holly rockabilly songs and played the American airforce bases in East 
Anglia. At the beginning of 1962 they were auditioned by Decca where, notoriously, they were chosen to be given a contract over the other group being auditioned-which was the Beatles. One story is that Brian Poole and the Tremeloes were preferred because they lived closer to Decca's London recording studio. A more likely reason is that their bouncy, poppy sound appeared more commercial-that is, it fitted more with the English tradition of light entertainment. Understandably, given their musical origins, Brian Poole and the Tremeloes' music sounds even whiter than that of Gerry and the Pacemakers. The jaunty rhythm is complemented by the group's simple three part harmonies. The vocals are drained of all emotion leaving the lyrics to carry the expression. Bruce Eder writes of them: 'They were one of the more prodigiously talented British pop/rock bands of the 1960s, and they threw their talent into the making of amazingly catchy and wellcrafted singles.' 22

That Brian Poole and the Tremeloes were positioned within an English pop tradition that meshed with the mainstream English Variety tradition of entertainment was something well appreciated by Owen in her review of the 'Liverpool Sound' show:

'Brian Poole and the Tremeloes were a well-integrated act who used the comic talents of a couple of their members.

Their version of "Michael Row the Boat Ashore" was unsophisticated and hilarious. $^{23}$

'Michael Row the Boat Ashore' is an African-American spiritual from the nineteenth century. From what Owen writes, the group performed the song as a piece of light entertainment typical of the English Variety tradition.

We are, now, beginning to get a sense of the kind of music liked in Perth: English, inoffensive, Variety-oriented entertainment. The next group we can look at is Billy J. Kramer with the Dakotas. Where Gerry Marsden always saw himself as the frontman and leader of a unified group, Billy J. Kramer's relationship with the Dakotas was similar to that of Cliff Richard with the Shadows - a structure which had typified English music before the beat groups. Zion has commented on the persistence of this structure in Australia after the advent of the group style typified by the Beatles: 
'What was different in Australia was the extent to which the old guard became role models for new performers. For of the pop acts that emerged during the mid-1960s a significant proportion were presented as solo performers in keeping with the styles that had emerged in the late 1950s. ${ }^{24}$

Here, we can also cite Brian Poole with his imitation of Buddy Holly as another example. In Perth, this preference for a solo singer with a group of backing musicians persisted more strongly than in the rest of Australia. Zion writes about Melbourne's Normie Rowe with his backing group the Playboys as an example of this continuity, however the better example would be Perth's most successful artist during this period, Johnny Young, who began his career fronting a group called the Nomads. He then put together his own backing group, Kompany, before finally going solo. The reason for this preference in Perth would likely be the impact of English migrants who had arrived before the beat boom and continued to prefer the kind of music that they remembered from before they had left Britain.

Billy J. Kramer was a Liverpudlian and, indeed, was also managed by Brian Epstein which is how it came to happen that Kramer's first two singles, 'Do You Want To Know A Secret?' and 'Bad To Me,' were both written by Lennon and McCartney, as was his fourth single, 'From A Window.' In Britain, 'Do You Want To Know A Secret?' got to number two. In Australia in 1963 it reached number sixty-two nationally but number eleven in Adelaide and number thirty one in Perth. It would be safe to say that, as with the chart placings of other English acts it was the high proportion of British migrants in Adelaide and Perth which resulted in high placings in these cities that pulls up the artists' national placing. What we can also see is that, again, the Perth audience was slower to pick up on the artist than Adelaide. This may well have been because, at first, he was perceived as the lead singer of a beat group rather than as a solo singer and his music was heard as beat music.

Once Perth did accept them, though, as we have seen with Brian Poole and the Tremeloes, Billy J. Kramer with the Dakotas did better in Perth than Adelaide. 'Bad To Me' (1963) reached number eighteen nationally, number fifteen in Adelaide but number 
seven in Perth; 'Little Children’ (1964) reached number ten nationally, number eight in Adelaide and number three in Perth; 'From A Window' (1964) reached number eighteen nationally, number twenty in Adelaide but got to number three in Perth. Kramer's popularity would have rested on the identification of his light, entertaining singing style coupled with his choice of melodic pop songs.

Not only was the structure of Billy J. Kramer with the Dakotas in the pre-beat group form of solo singer and backing musicians but the Lennon and McCartney compositions they recorded were at the light entertainment end of the composers' workmore McCartney than Lennon, if you like. As Ritchie Unterberger writes: 'All these tunes...represented Lennon-McCartney at their lightest and most facile, which to a large degree explains why they didn’t record the numbers for their own releases, deeming them more suitable for Kramer's bland approach. ${ }^{25}$ Once again, then, we find it is the English pop sound, the sound that fits in with the English music hall and Variety tradition of entertainment, which is more popular in Perth than anywhere else in Australia, including Adelaide.

In case there remains doubt, I will offer one more example, that of Herman's Hermits. From Manchester, Herman's Hermits formed in 1963 as the beat-group sound was starting to take over from solo singers with backing musicians. Nevertheless, fronted by Peter Noone who had been a successful child actor, appearing in the soap-opera Coronation Street, for example, the group had a structure more traditional than, say, Gerry and the Pacemakers. The group's early hits were produced by pop impresario Mickie Most and had that bouncy beat and catchy melody which was characteristic of the English pop style of the early 1960s and which we are now familiar with as the style most popular in Perth. It should, therefore, be no surprise to find that their first single, 'I'm Into Something Good’ (1964), while reaching number eleven nationally, got to n umber three in both Adelaide and Perth. Their next single, 'Show Me Girl,' made number twenty five nationally, number twenty six in Adelaide and number five in Perth. Herman's Hermits acknowledged their relationship to the music-hall tradition when they recorded 'Mrs Brown You've Got A Lovely Daughter' (1965) which, though contemporary, was written in the music-hall style. In Britain, the song was not released as a single because the group were fearful of jeopardising their beat group image. 
Released in Australia, the single reached number one not only in both Adelaide and Perth but nationally across Australia demonstrating the importance of the English musical inheritance even in cities with a lower percentage of British migrants. The same general pattern of the group's singles doing as well if not better in Adelaide than nationally and best in Perth persists across the group's releases until they broke up in 1968.

\section{Johnny Young and Middle-Class Entertainment}

Perth got its first recording studio in 1962 when it was opened by twenty-two year old Martin Clarke. For the first few years Clarke's time was spent doing every conceivable kind of recording, from prime ministers to synagogue voices, military bands, all types of choirs. ${ }^{26}$ Around 1966 Clarke purchased a four track tape recorder and started to record popular music which he released on his own Clarion label.

In early 1966 Clarke recorded Johnny Young singing 'Step Back’ with the B-side, which became a double A-side, of 'Cara-Lyn.' The single did very well in Perth and reached number two nationally. 'Step Back' was written by George Young and Stevie Wright of the Easybeats. In 1966 the Easybeats were at the peak of their popularity. It needs to be noted, though, that their sound, with a fairly heavy, driving beat and Wright's tendency to scream and generally emote his vocals, a sound influenced almost as much by the English rhythm and blues groups as the poppier sound of the Beatles and the Merseybeat groups, meant that the group was rather less popular in Perth than in the other major cities. For example, 'Wedding Ring' (1965) reached number seven nationally but only number eighteen in Perth and 'Come And See Her’ (1966) got to number three nationally but only number fifteen in Perth.

The story goes that, when the Easybeats visited Perth, Young, who was already well-known locally both as the compere of the local Channel 7 pop music program, Club 17, and as a performer in his own right, asked Young and Wright for a song. At this time Young was backed by Kompany. Young has a light, bright, tenor voice, clear with no vibrato. Kompany play in a bouncy, almost jaunty style more typical of the Tremeloes or Herman's Hermits than the Easybeats—a style typical of the English music liked in Perth at that time. The recording, like Young's later releases, places his voice out in front, making it clear that he is a solo singer. In Young's interpretation, 'Step Back' became a 
catchy piece of likeable pop. Young was already well on his way to becoming an easylistening entertainer in the tradition of Cliff Richard. ${ }^{27}$

It is worth spending a moment in 'Cara-Lyn.' This is a cover of a song originally written and recorded by the Strangeloves. The Strangeloves were an American group formed in the wake of the British Invasion, the term used to describe the impact of the beat groups on American popular music. The Strangeloves were actually three Brill Building songwriters. ${ }^{28}$ Not surprisingly, then, their songs were always lighter and more melodic that the garage bands with whom they are often classified and, with their infectious, catchy rhythms these songs did bear a similarity to the songs the group was imitating. The influence flowed both ways. Lennon and McCartney acknowledged Gerry Goffin and Carole King as their favourite composers and, indeed, covered a Goffin and King song, 'Chains,' and another Brill Building composition, 'Baby It's You,' on Please, Please $M e .^{29}$ Herman's Hermits' first hit, 'I'm Into Something Good,' was a Goffin and King composition. It is also understandable, then, that Brian Poole and the Tremeloes would cover the Strangeloves' biggest hit, 'I Want Candy,' and that the group would have its biggest success in Australia in Perth, where their own version of 'CaraLin' (this is the original spelling) got to number twenty six in 1965, the year before Young recorded it in an even lighter and poppier style than the original.

In Perth, as we have already seen for the other capitals, and especially Adelaide, a disproportionate number of the young men who started singing and playing in groups in the early-to-mid-1960s were migrants. Russ Kennedy, of Russ Kennedy and the Little Wheels, was American. Alan Trosser, who replaced Sydneysider Terry Walker after three singles in one of Perth's earliest beat groups, the Times, was English. Bon Scott who was in the Spektors and then the Valentines, but who is best known for his work singing with AC/DC in the 1970s, was Scottish. Wyn Milson, who played guitar in the Spektors, had a Welsh background. Robbie Snowden, another solo singer, was English. Johnny Young, originally John Benjamin de Jong, was born in Rotterdam, in the Netherlands, where two of the Easybeats also came from, in 1945 and came to Perth with his parents when he was three. 
Round about 1962 Young organised dances at Port Beach, in Fremantle, where he would sing with the Nomads. Maureen, a friend of Bon Scott, told this story to Clinton Walker who published it in his biography of Scott:

، "We all used to go to the stomps down at Port Beach, but we didn't like Johnny Young, we thought he was a poof or something, so we used to call out, We want Bonnie! We want Bonnie!

Bon would jump up and have a sing, but he wouldn’t do some wimpy ballad, rather a rock'n'roll song like "Long Tall Sally” or "Blue Suede Shoes". ${ }^{30}$

The tension, here, that Maureen is describing, and which comes out in Scott's and Young's musical choices, is class-based. Scott came from a working-class background in Fremantle, Young's more middle-class family lived in the semi-rural suburb of Kalamunda.

Previously, following Zion, I have described Young as a solo singer, a type which has had a more prominent and longer lasting existence in Australia than Britain. Johnny Farnham, who had his first hit in 1968 with another imitation music hall song, 'Sadie (The Cleaning Lady)' is a more recent example. Now I want to suggest that the differences between Young and Scott are a reprise of the differences in the late 1950s between Johnny O'Keefe and Col Joye, and that Young can be understood as part of a tradition that runs from Joye to Ray Brown of Ray Brown and the Whispers to Johnny Farnham. The point here is not about the singers' actual class of origin but more about the class values that underlie the way they express themselves. Thus, as Zion points out, O'Keefe, whose father was Mayor of Waverley in Sydney, was from a middle-class background but his uninhibited and sexualised performances were anathema to the acceptable behaviour of the middle class who preferred the bland, enjoyable entertainment provided by Col Joye and Ray Brown. ${ }^{31}$

In The Young Ones I quote extensively a respectable middle-class woman's memories of watching O'Keefe who, she says, “"we absolutely loathed”' because "“He was rude...he used to gyrate and do things with that long microphone and we would sit there with our mouths open”. ${ }^{32}$ Pamela's preference was for the more polite 
entertainment of Col Joye. Maureen, Bon Scott's early fan, would have preferred O’Keefe. She notes that when Scott performed at Port Beach:

“"All the girls used to go wild over him, and I think that caused a bit of trouble. Johnny Young used to get pretty upset”, 33

Conversely, Zion quotes George Young of the Easybeats describing Ray Brown and the Whispers' repertoire as 'wimpy lightweight songs' and Zion goes on to write that Young continued:

، "At that time [Brown] had it all going for him so far as commercial success was concerned, but as far as people like us were concerned he had no musical credibility at all. Zero. Zilch. He did not have one iota of what we were all about”, 34

Bon Scott might have said something similar about Johnny Young but it was Young's music that reflected the dominant musical taste in Perth in the 1960s exemplified, as we have seen, in the preference for the music of Brian Poole and the Tremeloes and Herman’s Hermits.

In June 1967, with four national hit singles behind him, including a slowed down and much sweetened, schmaltzy ballad reworking of the Beatles' 'All My Loving' which became his signature song, Young sailed for England. Over the next six months he released two songs composed by the Gibb brothers of the Bee Gees. Both did well in Australia but failed to chart in England. By early 1968 Young was back in Australia having run out of money. The story goes that it was bad luck, that the first single, 'Craise Finton Kirk,' was being heavily played on the pirate radio ship, Radio London, but that, when that station was forced off the air, Young's opportunity to break into the British charts went with it. The reality is rather different. In England in 1967 there was little interest among young record buyers in sweet-sounding male singers. Young might have succeeded in Variety, as an entertainer, but, for that older market he sounded too youthful when compared to Engelbert Humperdinck's baritone. In short, in England in 1967/68 Johnny Young was an anachronism.

\section{Beat Groups in Perth}


As one would expect from the preceding outline of the imported music preferred in Perth, the music played by local artists also had a sweeter sound that had a greater similarity with the lighter, pop sound of Brian Poole and the Tremeloes and Herman's Hermits than the edgier work of the Beatles or, from around 1965, the harder, beat-driven sound of the English rhythm and blues groups such as the Rolling Stones, the Yardbirds and the Northern Irish group, Them. In the liner notes for the Clarion retrospective, Clarion Call, Alex Palao writes that the Times are described as 'Perth's first true beat group. ${ }^{35}$ Clarion released their first single 'Glad Not Sad,' in 1965. It reached number six in Perth and number sixty-nine nationally. Palao provides this musical history for the group: 'Despite a vaguely moptop image, the trio's initial recordings such as their rare debut EP The Sound Of Our Times had a skiffle, almost rockabilly feel. ${ }^{36}$ Lonnie Donegan had popularised skiffle in England with 'Rock Island Line’ in 1956 and a string of subsequent releases. While 'Rock Island Line' did well in Australia, reaching number three nationally, Donegan's only other hits were novelty songs. The Times were some years behind the time and their skiffle influence was probably the consequence of the knowledge brought out by British migrants in the late 1950s - the same cohort of people (though not necessarily the same people) who would have preferred Cliff Richard to the beat groups. 'Glad Not Sad,' though, is Beatles-influenced not only in its beat group formal structure but also in its melody. It was written by the lead singer, Terry Walker, who, as I have already mentioned, was a Sydneysider who had moved to Perth and brought his liking for beat music with him. At the same time, in spite of Walker's slightly gravely and assertive vocal, the bounce in the beat made the song sound more reminiscent of Gerry and the Pacemakers which was no doubt another reason, in addition to the hometown advantage, why the group did so much better in Perth than elsewhere in Australia.

The Spektors were, perhaps, the toughest group in Perth around 1965 both in their membership, Bon Scott from Fremantle and Milson from working class Kwinana where BP, then the Anglo-Iranian Oil Company, had opened an oil refinery in 1955 and Alcoa an alumina refinery in 1961, and in their repertoire. Walker tells us that: 'Their set consisted of Stones' songs, Them's “Gloria," and the Beatles' "Yesterday”. " ${ }^{37}$ He also writes that The West Australian described the Spektors as 'one of Perth's top five rock 
groups. ${ }^{38}$ John Collins was the main singer, Scott played drums and stepped forward to sing on occasion. Indeed, in that conventional form I have already discussed, and reflecting Perth's conservative taste, the group were sometimes known as John Collins and the Spektors.

While the Spektors never released a single, Clarke recorded three of their songs at Clarion for the group to mime to on the television show Johnny Young hosted, Club 17. These were 'Gloria,' 'On My Mind' and 'Yesterday.' The group's repertoire tells us a lot. Their choice of material by the Rolling Stones and Them suggests their bid for a harder-edged, rhythm and blues influenced sound but 'On My Mind' and 'Yesterday' pull the group back to the softer, bouncier beat so prevalent in Perth. 'On My Mind' was the B-side of a 1964 single by Mike Berry who had started out as an English rock'n'roller influenced by Buddy Holly. Indeed, Berry's biggest hit was his 1961 release 'Tribute To Buddy Holly.' On their version of 'On My Mind,' the Spektors sound like the Beatles from around 1963. 'Yesterday' is, of course, the McCartney ballad. Collins' voice has a timbre somewhere between the voices of McCartney and Lennon. It certainly does not have the rasp of Mick Jagger's voice. In other words, even in the Spektors we find the slide towards the sweeter end of beat music which characterised Perth's musical taste.

The Spektors' version of 'Gloria' was sung by Scott. Van Morrison wrote the song and Them's version has a musical intensity coupled with Morrison's powerful and often almost screamed vocal which has always marked the song out as a challenge for artists wanting to cover it. Scott's vocal has none of the excess, the attack, the screaming for which he would later become known as the singer in AC/DC. While his version of 'Gloria' may have sounded quite daring, and indeed possibly shockingly excessive, in Perth in 1965 it was quite tame compared to Them's original.

In late 1966 Scott and Milson joined forces with two members of the Winztons and the drummer from the light beat group, Russ Kennedy and the Little Wheels, to form the Valentines. Vince Lovegrove, from the Winztones, and Scott shared the vocals. Lovegrove came from middle-class Applecross. In 1961 he had been Cliff Richard to a group called the Dynells who were 'a Shadows-type band. ${ }^{39}$ The Valentines immediately became the biggest group in Perth and, in January 1967, they played to an 
audience of 3,000 at a concert for Torchbearers for Legacy in the Supreme Court gardens. ${ }^{40}$

Walker writes that: 'The Valentines' repertoire consisted mainly of soul coversSam and Dave and Wilson Pickett (the roots of the Rolling Stones)—plus songs by mod staples like the Who, the Small Faces and Spencer Davis. ${ }^{41}$ Playing songs by these artists the group must have been looking for a harder, rockier sound than had been the norm among Perth groups. Their first single, though, was a cover of Arthur Alexander's 'Every Day I Have To Cry' backed with a cover of the Small Faces 'I Can't Dance With You.' Alexander was a countryish soft soul singer. The Beatles had covered his composition 'Anna (Go To Him)' on Please, Please Me. 'Every Day I Have To Cry' is a catchy ballad and the Valentines' version was most probably filtered through the Bee Gees' melodic version which had been released in Britain in 1965. 'I Can't Dance With You' has a certain power but neither Lovegrove nor Scott can match the energy and vocal explosiveness of Steve Marriott. In other words, try as the group members did to give the group a harder, more rhythm and bluesier sound, they remained affected by the Perth taste for sweetened, bouncy pop.

The Valentines released another single, 'She Said,' as they left for Melbourne in mid-1967. 'She Said' was a light, sub-psychedelic confection written by the Easybeats' Wright and Young. It was backed by a sweet, harmonised version of 'To Know You Is To Love You.,' composed by Phil Spector in 1958 for his group, the Teddy Bears whose lead singer was a sixteen-year-old girl named Annette Kleinbard. Spector’s original has 'him' rather than 'you' in the title and the lyrics. Providing the source for the Valentines' version, the English pop, harmony duo, Peter and Gordon's 1965 cover has 'you.' In the end, as I have already remarked, the Valentines became a bubblegum group and it was as such, appealing to young female teens, that they had most success nationally. 'My Old Man's A Groovy Old Man' reached number twenty one in 1969. On amazon.com a reviewer from Las Vegas provides a write-up of the CD that contains the Valentines' early singles for Clarion. He suggests the group sounds:

'something like a cross between the Monkeys [sic] and the Mamas And The Papas [sic] — but a bit sub par to either of those bands. Lovegrove, 
definitely the main vocalist, is going for a Paul McCartney clone sound sometimes, and really fits the role and image the band is trying to achieve. $^{42}$

What this reviewer was hearing is the sweetness, and the whiteness, that is, here, the emphasis on melody and the lack of emotion in the vocal expression, that pervaded Perth's musical taste during the 1960s.

\section{English Rhythm and Blues in Adelaide}

The artists who, in the first half of the 1960s, reached higher chart positions in Adelaide than either Perth or nationally were the English rhythm and blues based groups. Now, in Britain, although there was significant overlap, the beat groups and the rhythm and blues groups developed in different circumstances. To simplify a complex history, the beat groups evolved out of the skiffle scene and the impact of American rock'n'roll, more especially the rockabilly inflection as popularised by artists like Gene Vincent, who lived in England for a time, and Buddy Holly. They were also very influenced by African-American artists such as Little Richard and Chuck Berry who are often considered to have evolved the rock'n'roll rhythm. These influences were synthesised with the English popular-music tradition that came from late-nineteenth and earlytwentieth century music hall, a tradition which provided the bouncy beat and catchy, sing-along choruses that were typical of the songs of groups such as Gerry and the Pacemakers and Herman's Hermits.

The rhythm and blues groups developed out of a specialised interest among some young people with the African American musical tradition, most especially the blues. One stimulus for this interest was the tours by blues artists in the second half of the 1950s. Philip H. Ennis writes of 'an increased pace in the R\&B tours to the United Kingdom, including Big Bill Broonzy, Sonny Terry and Brownie McGhee, and Muddy Waters, implanting there a crop of young bands enamoured with the purity of the blues and its modern offshoots. ${ }^{43}$ Another stimulus was the popularity of trad jazz which evolved into an interest in other African-American musical forms such as blues and rhythm and blues. This, in turn, was stimulated by Lonnie Donegan's reworking of some African-American songs in skiffle form. At the time he developed the skiffle sound, 
Donegan was playing with Chris Barber's Jazz Band. The interest in rhythm and blues was primarily among middle-class youth. As Dick Bradley writes:

'The rhythm'n'blues-based groups of the early 1960s tended to have a more middle-class and 'intellectual' audience and background than the original Beat groups, and were especially popular in the universities, art colleges and sixth forms. ${ }^{44}$

However, as Bradley goes on to counsel, this distinction should not be exaggerated. By the mid-1960s what distinguished these rhythm and blues-based groups most was the harder edge that there music had-generally speaking, the more intense guitar work, the more driving beat and more emotionally uninhibited vocals. All these elements had been learnt from the African-American artists whose music had provided these groups with a template.

Glenn A. Baker, the Australian popular music archivist from Sydney, notes that: 'Where I grew up the Yardbirds hit home a little harder than the Beatles.' 45 In Australia, as in the United States, no generic distinction was made between the beat groups and the rhythm and blues groups and, indeed, in Britain by the mid-1960s this was true also. Rather, the groups were experienced along a spectrum from sweeter and more blandly entertaining to harder and more emotionally involving and, in this sense, more threatening to a middle-class order that valued reason and politeness. While it was certainly the case that the liking for rhythm and blues developed in middle-class youth this was not a mainstream preference. It was these rhythm and blues groups, including the Yardbirds, the Pretty Things and the Animals, that were more popular in Adelaide than Perth. The Rolling Stones were the most popular of the rhythm and blues groups and, like the Beatles and, indeed, Gerry and the Pacemakers, their level of popularity was such that it is hard to find any consistent divergence in the chart placings of their releases across Perth, Adelaide and nationally. Nevertheless, there is a consistency for Adelaide to the top ten placings of the Stones' releases in 1964 and 1965 which is greater than for Perth and nationally.

The divergence is clearer when we examine the Yardbirds' chart placings. The London-based Yardbirds were formed at Kingston Art School and started out playing 
versions of Chicago blues by the likes of Muddy Waters and Sonny Boy Williamson. In 1965 they began to play a form of rhythm and blues-influenced rock music that, often, had a psychedelic element to it. At this time Eric Clapton left the group notoriously protesting at the group's move away from the blues.

The Yardbirds' first single, 'For Your Love,' (1965) reached number eighteen in Adelaide, number twenty eight in Perth and number twenty two nationally. 'Heart Full Of Soul' (1965) reached number thirteen in Adelaide, number nine in Perth and number fifteen nationally. This relative popularity in Perth was not to be repeated. 'Still I'm Sad' (1965) reached number seven in Adelaide, number twelve in Perth and number twenty six nationally. The group's next single, at the end of 1965, was their version of Bo Diddley's 'I'm A Man.' The strong African-American influence may have been one reason the single appears not to have made Perth's top forty. It did, however get to number one in Adelaide and number seven nationally. The pattern of releases doing best in Adelaide, and then usually better nationally than in Perth, continued. In 1966, for example, 'Shapes Of Things' reached number two in Adelaide, number six nationally but only number nineteen in Perth. 1967's 'Little Games' got to number ten in Adelaide, number thirty nationally but only reached number fifty in Perth.

The Animals formed in 1962 in Newcastle fronted by Eric Burdon who had a very distinctive, gravel-voiced delivery. Their first single was a version of the traditional southern American folk song, 'House Of The Rising Sun' (1969). It was produced by Mickie Most, whom we have already met producing Herman’s Hermits' early hits. Most achieved a recording which became a major hit in Britain crossing over from the minority rhythm and blues audience to the mainstream pop audience. The release was equally popular in Australia where the record climbed to number two in Adelaide and nationally, and reached number one in Perth. Neither of the group's subsequent releases made the Perth top forty while 'I'm Crying' (1964) reached number eighteen in Adelaide and number forty nationally and 'Boom Boom,' a blues song composed by John Lee Hooker, reached number nineteen in Adelaide and number thirty nine nationally.

There is a similar pattern for Them, the Belfast-originated rhythm and blues group fronted by Van Morrison. 'Baby Please Don’t Go' (1965), an old blues by Big Joe 
Williams, got to number seven in Adelaide, number forty five nationally but did not chart in Perth. The group's next single, the catchy 'Here Comes The Night' which, like 'House Of The Rising Sun,' was a crossover pop hit in Britain, achieved the same result in Australia getting to number seven in Adelaide, number seventeen nationally and number two in Perth. However the bluesier 'Mystic Eyes' (1965), which got to number two in Adelaide, only reached number forty three nationally and number forty nine in Perth. 'Gloria,' which we have seen the Spektors cover in Perth, got to number three in Adelaide, number twenty-two nationally but did not chart in Perth.

Perhaps the most extreme example of the pattern I am describing here involves the releases of the Pretty Things. Around 1964 and 1965 the Pretty Things were often compared to the Rolling Stones but if, with manager Andrew Loog Oldham's help, the Stones constructed an image of badness just this side of being totally unacceptable, the Pretty Things took their image into that totally unacceptable territory. Oldham developed a press campaign for the Stones based on the question: 'Would you let your daughter marry a Rolling Stone?' The Pretty Things' image suggested that such a conventional practice as marriage was not on their agenda. Coming out of a similar range of rhythm and blues influences to the Stones, the Pretty Things' music was harder, more intense and was generally experienced as even more aggressive. Only one of their singles charted in Perth, 'A House In The Country' (1966), which reached number twenty three. It got to number thirteen in Adelaide but only number sixty-three nationally. This radical discrepancy characterised the reception of the Pretty Things' releases in Australia. For example, 'Honey I Need' got to number six in Adelaide but only number thirty four nationally. Their version of 'Cry To Me' (1963), made famous by Solomon Burke, reached number thirty in Adelaide but did not chart nationally. 'Midnight To Six Man' reached number five in Adelaide but only number sixty two nationally. The pattern was similar for the rest of the Pretty Things' releases through 1965 and 1966. Extrapolating, it seems that the Pretty Things' music, with its rejection of middle-class moderation in its powerful attack and its emotional expression, spoke to a large segment of the British working-class youth who had migrated to Elizabeth and the nearby suburbs with great hope for a better future but found themselves instead in a strange land trapped in factory jobs in heavy industry. 


\section{Perth, Adelaide, Popular Music and Class}

In Perth, there was no large scale heavy industry such as the GMH manufacturing plant. Nor were British migrants attracted to the city and then encouraged to a new suburban centre in order to provide labour for that plant and other industrial enterprises. Few left Perth to go to the mining sites in the Pilbara. In Adelaide, in 1960 the Weapons Research Establishment employed 2,635 people ${ }^{46}$ and in 1965 GMH employed 7,745 manual workers across their Elizabeth and Woodville sites. ${ }^{47}$ In Perth, the numbers employed in the Kwinana refineries were nowhere near these figures. By 1978 the total population of the Kwinana area was, in the words of a booster history of the area, 'more than 14,500. ${ }^{48}$ It was only at this time that Kwinana was formally classified in local government terms as a Town. ${ }^{49}$ The other large employer of working class labour in the Perth-Fremantle area were the Fremantle docks, and these had no requirement for a sudden increase in labour. ${ }^{50}$ In Perth, then, while British migrants did concentrate in certain areas, this was not allied to any local need for large-scale working-class labour. Indeed, Perth was not primarily an industrial city. Its wealth was produced in its huge hinterland, firstly from pastoralism but, increasingly from the 1920s onwards, from mining and resources more generally.

In the 1960s Perth saw itself as a wealthy, suburban, middle-class city. As Robert Fishman writes, suburbia 'was an archetypal middle-class invention' ${ }^{51}$ which, he goes on to argue, 'is more than a collection of residential buildings; it expresses values so deeply embedded in bourgeois culture that it might also be called the bourgeois utopia., ${ }^{52}$ Perth, built on wealth generated elsewhere in primary industry, where there was little in the way of an industrial working class, was able to construct a totalising image of itself as middle class.

Writing about the United States, Christopher Lasch has argued that:

'The self-made man, archetypal embodiment of the American dream, owed his advancement to habits of industry, sobriety, moderation, selfdiscipline, and avoidance of debt. He lived for the future, sunning selfindulgence in favor of patient, painstaking accumulation. ${ }^{53}$ 
The values that Lasch lists, most of which are derived from Max Weber's classic account of the relationship between the Protestant work ethic and the development of capitalism, are central to middle-class ideology. They pervade the worldview of the Australian middle class and, in the 1960s, in Perth where there was no large-scale working class to challenge these values, they were central to Perth's way of life and the way the inhabitants of Perth saw their city. These values were also typified in the kind of enjoyable, entertaining beat music preferred in Perth.

Veronica Brady has written about what she calls 'the Arcadian strain in Western Australian writing' which she suggests is not surprising 'in a society founded by English gentlefolk in search of the "good old days" which, it seems, would not come again in England. ${ }^{54}$ This nostalgic yearning combined in Perth with a middle-class sense of the city as a utopian idyll. In Perth, those skilled, semi-skilled and unskilled British migrants, regardless of the actual jobs they got, could relax into a fundamentally middleclass lifestyle and believe that they had achieved the better life for which they had hoped when they migrated. The music that was most popular in Perth, typified in the songs of Brian Poole and the Tremeloes, was an expression of this middle-class attitude. Moreover, while the beat groups had attained a greater popularity in Adelaide than nationally because, it would seem, of the British migrant influence, in Perth, there was an almost complete rejection of the English rhythm and blues-based groups that were so popular in Adelaide.

Whether it was a rejection of middle-class values or an assertion of working-class values what was happening in Elizabeth was an acceptance of emotional involvement in both the performance of popular music and its reception. Zion quotes Colin Beard who, in the early 1960s, worked as a photographer for the popular music magazine, Go-Set. Talking about the patrons at dances in Elizabeth he says:

' "the way that they reacted to everything, and it was far more warm, far more heartfelt. It was almost like jungle music!...

I remember thinking at the time that they seemed to be enjoying it more; I mean they seemed to be allowing themselves to [let] go more, it seemed to be their music. ${ }^{55}$ 
What Beard is describing is a version of the emotional involvement that we have already discussed in relation to Johnny O'Keefe and Bon Scott. In light of this, the Pretty Things' lack of success in Perth is understandable; they and their music were everything that Brian Poole and the Tremeloes and Herman's Hermits were not. Or, to put it differently, the Pretty Things, and the other rhythm and blues groups, challenged the values of entertainment and middle-class decency which were espoused by the groups that were so successful in Perth.

There was another set of groups that were more successful in Adelaide during 1966 and 1967 than elsewhere in Australia. These have come to be collected together under the heading of garage bands but at the time they were making records they were heard as American versions of the English rhythm and blues groups. This is not surprising as the garage band sound was itself influenced by those groups. As Paul Kauppila writes:

'Garage rock could be defined as a musically simple, blues-based form of popular music influenced most heavily by the British Invasion bands of the mid-1960s, particularly the Beatles and Rolling Stones, but also encompassing the Animals, the Kinks, the Yardbirds, Them and the Who. ${ }^{56}$

In 1966 Count Five's 'Psychotic Reaction' climbed to number six in Adelaide, number twelve nationally and, again probably because of its catchy chorus, number ten in Perth. Kauppila notes that: "The sound of "Psychotic Reaction"...was influenced by the Yardbirds with some critics going so far as to call the song a "rip off" of their sound. 57 This similarity may well have helped in the song's success in Adelaide while, in Perth, Count Five's lighter, poppier touch helped the song to a greater acceptance. In 1966 the Standells' 'Sometimes Good Guys Don't Wear White' got to number seventeen in Adelaide, number ninety two nationally and did not chart in Perth. In 1967 the Electric Prunes' 'I Had Too Much To Dream (Last Night)' reached number nine in Adelaide, number sixty seven nationally and number forty six in Perth. However, it is with the Seeds, one of the harder-sounding rhythm and blues-based garage bands that we find most clearly the distribution we have become familiar with when looking at the relative 
popularity of the English rhythm and blues groups. None of the Seeds three singles charted in Perth. 'Pushin' Too Hard' (1966), though, reached number three in Adelaide and number sixty two nationally, 'Mr Farmer' reached number twenty six in Adelaide and number eighty five nationally and 'Can't Seem To Make You Mine' got to number twenty two in Adelaide and number eighty seven nationally.

Garage-band music is usually thought of critically as expressing a disillusion with suburbia and 1960s society generally. Michael Hicks, in his book-length discussion of garage bands, Sixties Rock: Garage, Psychedelic, and Other Satisfactions, suggests that, “ " garage band” implies a distancing from more respectable bands (and from more respectable social enterprises in general). ${ }^{58}$ Kauppila writes that, in spite of American affluence and the optimism it engendered:

'other social realities militated against this positive feeling for example, the Cold War and its threat of nuclear annihilation, the Kennedy assassination, the impending Vietnam War, the cookie-cutter nature of the developing suburbs, etc. Ergo, there was a feeling of rootlessness and alienation and young people were looking for cultural experiences that reflected this. ${ }^{59}$

He argues that garage-band music was one of these cultural experiences. In Elizabeth, garage-band music, like that of the English rhythm and blues groups, spoke to the disillusion and alienation of the British migrant youth and helped to affirm their sense of working class community.

This has been a tale of two cities and two different migrant experiences. For the mostly working-class British migrants who settled in Perth, Perth offered itself as a wealthy, middle-class city in which they could think of themselves as upwardly mobile. In Adelaide, the British migrants found themselves channelled into a new town, built away from Adelaide itself, where they were expected to find employment in classically working-class circumstances as workers in large-scale industrial manufacturing enterprises. In Perth the music that became popular was the light, poppy entertainment that dealt in the values of moderation and restraint which typified the middle class pleasures of English Variety. In Adelaide, where this music also had a hold, the harder, 
more emotionally involving music of the British rhythm and blues groups and the American garage bands was more popular. Although this music had originated in England with rebellious middle class youth, it was taken up in Adelaide by British migrant youth who felt themselves to be trapped in the kind of employment from which they and their parents had migrated in the hope of escaping and bettering themselves. In middle class Perth this music was, to all intents and purposes, completely rejected. In the rest of Australia, which, most importantly includes the major centres of Sydney and Melbourne, the kinds of music I have discussed here were less important. There is a clear correlation between the high percentage of British migrants in Adelaide and Perth and the importance of English music in those cities. Over the next twenty years, Adelaide became a cradle for suburban, working class Oz Rock, fostering groups such as Cold Chisel, the Angels and Redgum. Perth became a centre for good-time power-pop derived from English groups such as the Troggs and the Buzzcocks, though, ultimately, from the beat groups, producing bands such as the Manikins, the Hoodoo Gurus, the Boys, the Stems, the Chevelles, Jebediah and the Panics.

1 I need to add a note here about the charts that I am using for Perth, for Adelaide, and for Australia. For Adelaide and Perth my information comes from Gavin Ryan's Adelaide Chart Book 1959-2002, Moonlight Publishing: Golden Square, Victoria, 2003 and Perth Music Charts 1958-2006, Moonlight Publishing: Golden Square, Victoria, 2007. For the national charts, which include the Adelaide and Perth charts so this needs to be taken into account when thinking about the national figures, I have used David Kent's Australian Chart Book 1940-1969, Australian Chart Book Pty. Ltd,: Turramurra, NSW, 2005. The compilation of these charts by Ryan and Kent was by no means easy and straightforward. Both explain the intricacies of the charts that they used in their respective Introductions. Similarly, the assumptions behind the compilation of the original charts were not necessarily straightforward. Thus, what appear to be unproblematic chart positions are anything but. Nevertheless, I do believe that general points can be drawn from the careful compilations that Ryan and Kent have made. For the years under discussion Ryan was able to compile Top Sixty charts for Adelaide and Top Forty charts for Perth, Kent produced Top One Hundred charts dating back to 1958. 
2 Laurence Zion 'The impact of the Beatles on pop music in Australia: 1963-1966,' Popular Music, vol 6, no 1, 1987, p. 291.

A history of the Big Shows can be found in Alan Heffernan' Big Shows: The Lee Gordon Years. Heffernan was Gordon's accountant and became a kind of general manager for the Big Shows.

Glenn A. Baker The Beatles Down Under,

$5 \quad$ Zion 'The Impact of the Beatles...p. 294.

R.T. Appleyard British Emigration to Australia, pp. 114-115.

I.H. Burnley 'British Immigration and Settlement in Australian Cities, 1947-1971, International Migration Review, vol 12, no 3, 1978, p. 344. Adelaide and Perth,' p. 318

Mark Peel Good Times, Hard Times, p. 38.

Peel Good Times, Hard Times, p. 69. 
21 Rosyln Owen 'Screams From Audience At Capital Show,' The West Australian, Monday 6 April 1964, p. 14.

Bruce Eder 'Brian Poole and the Tremeloes' AllMusic Guide at: http://wm05.allmusic.com/cg/amg.dll?p=amg\&sql=11:3ifoxqr5ldse T1 .

Owen 'Screams From Audience ...'

Zion 'The Impact of the Beatles...,' p. 308.

Richie Unterberger 'Billy J. Kramer' on AllMusic Guide at: http://wm05.allmusic.com/cg/amg.dll?p=amg\&sql=11:0ifpxqe5ldde T1 .

Martin Clarke quoted in the liner notes for Clarion Call.

Young's later career is insightfully discussed in David Nichols 'Does the Meaning Mean a Thing?' Johnny Young's Hit Songs of the 60s-70s' Australian Cultural History, no 24, 2006, pp. 163-183.

On the Brill Building composers see Ken Emerson Always Magic in the Air: The Bomp and Brilliance of the Brill Building Era.

Emerson Always Magic in the Air, p. 195.

Clinton Walker Highway to Hell: The Life and Times of AC/DC Legend Bon Scott, p. 44.

Lawrence Zion 'Disposable Icons: Pop Music in Australia, 1933-1963, Popular Music, vol 8, no 2, 1989, p. 170

Pamela quoted in Jon Stratton The Young Ones, p. 153.

Maureen quoted in Walker Highway to Hell, p. 44.

George Young quoted in Zion 'The Impact of the Beatles...,' p. 305.

Alec Palao liner notes for Clarion Call

Palao liner notes for Clarion Call.

Walker Highway to Hell, p. 51.

Walker Highway to Hell, p. 51.

Vince Lovegrove quoted in Walker Highway To Hell, p. 43. 
$40 \quad$ Walker Highway To Hell, p. 55.

$41 \quad$ Walker Highway To Hell, p. 54.

42 Problem Child reviewing the Valentines Peculiar Hole In The Sky on amazon.com at: $\quad$ http://www.amazon.com/Peculiar-Hole-SkyValentines/dp/B00009VZD6/ref=pd_bbs_2?ie=UTF8\&s=music\&qid=119536855 $\underline{9 \& \mathrm{sr}=1-2}$.

43 Philip H. Ennis The Seventh Stream: The Emergence of Rocknroll in American Popular Music, p. 329.

$44 \quad$ Dick Bradley Understanding Rock'n'Roll, p. 78.

45 Glenn A. Baker in his liner notes for the Yardbirds collection Over Under Sideways Down.

Peel Good Times, Hard Times, p. 77.

$47 \quad$ Peel Good Times, Hard Times, p. 139.

at: http://kwinana.net/default.php?menu_id=10\&sub_menu_id=2 .

A useful outline of Kwinana's development during this period can be found in John Ewers (1971) The Western Gateway: A History of Fremantle, (Revised ed.), University of Western Australia Press, Perth, chapter 15 'The Kwinana Industrial Complex’.

A history of the Fremantle docks for the 1960s can be found in Malcolm Tull, (1997), A Community Enterprise: The History of the Port of Fremantle 18971997, St. Johns, Nfld., International Maritime Economic History Association, chapter 6 'Cargo-Handling Technology: Working Conditions and Industrial Relations on the Fremantle Waterfront'.

51 Robert Fishman Bourgeois Utopia, p. 3.

$52 \quad$ Fishman Bourgeois Utopia, p. 4.

Christopher Lasch The Culture of Narcissism, pp. 52-53. Writing Today’, Westerly, 1982, no. 4, p. 107. 
55 Colin Beard quoted in Zion 'The Impact of the Beatles...’ p. 298.

56 Paul Kauppila 'The Sound of the Suburbs: A Case Study of Three Garage Bands in San Jose, California during the 1960s' in Popular Music and Society, vol 28, no 3, 2005, p. 391.

$57 \quad$ Kauppila 'The Sound of the Suburbs,' p. 395.

58 Michael Hicks Sixties Rock: Garage, Psychedelic, and Other Satisfactions, p. 25.

$59 \quad$ Kauppila 'The Sound of the Suburbs,' p. 401. 